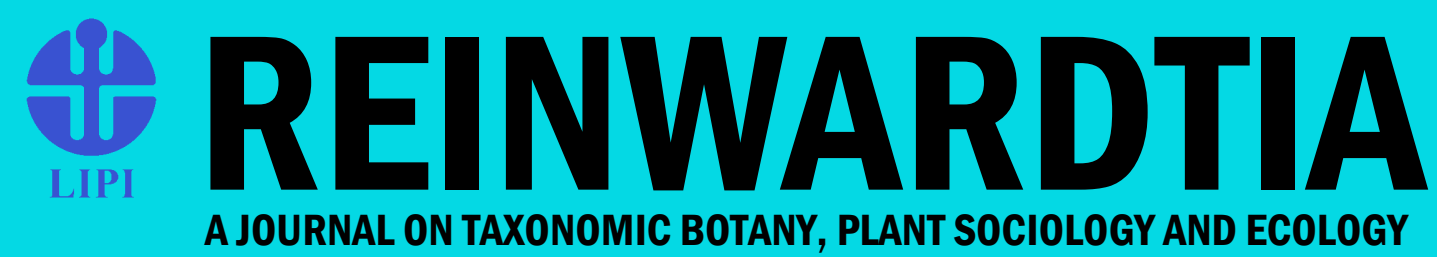

ISSN 0034 - 365 X | E-ISSN 2337 - 8824 | Accredited 792/AU3/P2MI-LIPI/04/2016
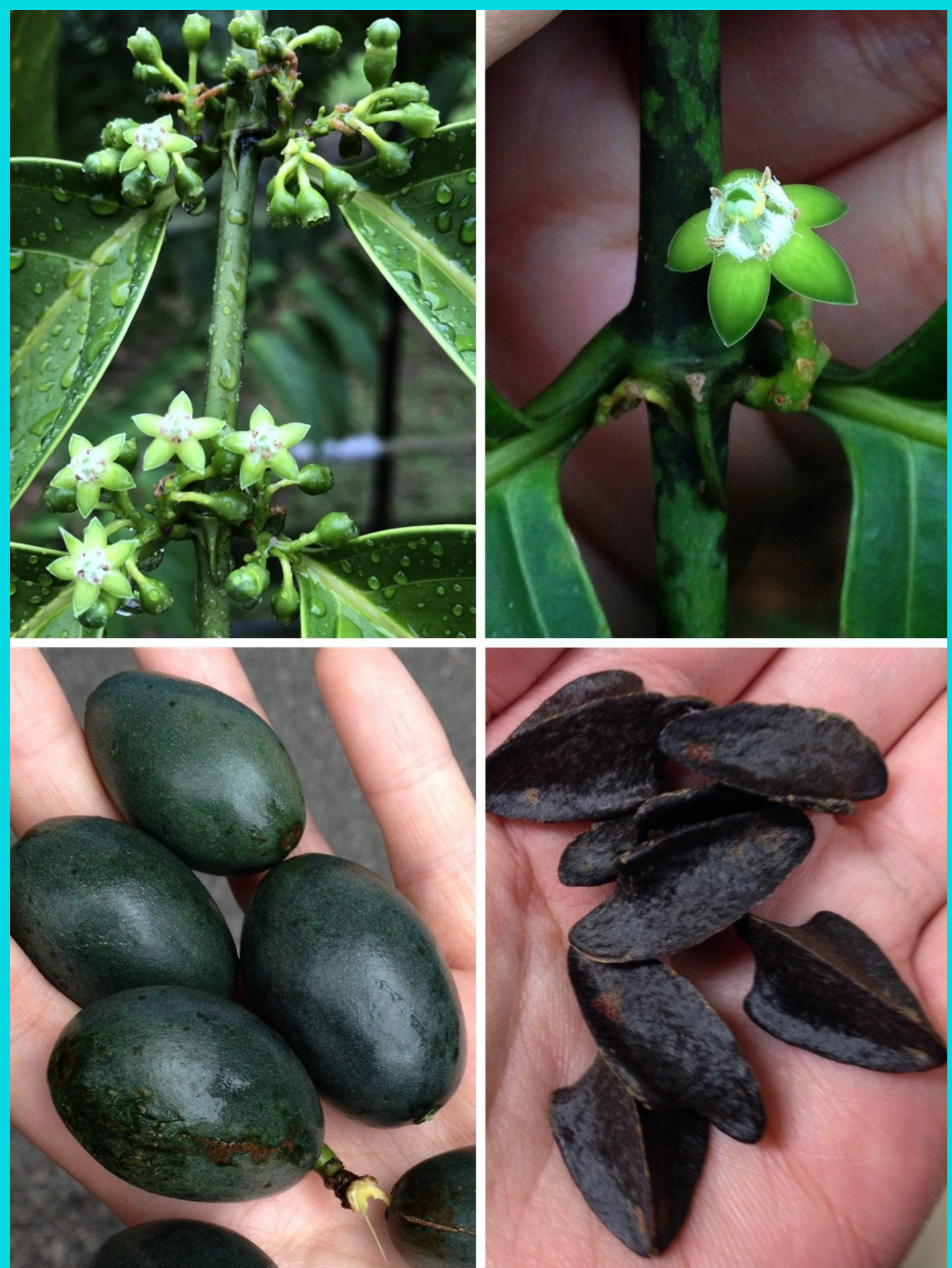

$201817(2)$ 


\section{REINWARDTIA}

\section{A JOURNAL ON TAXONOMIC BOTANY, PLANT SOCIOLOGY AND ECOLOGY}

Vol. 17 (2): 87 - 154, December 18, 2018

\section{Chief Editor}

Kartini Kramadibrata (Mycologist, Herbarium Bogoriense, Indonesia)

\section{Editors}

Dedy Darnaedi (Taxonomist, Herbarium Bogoriense, Indonesia)

Tukirin Partomihardjo (Ecologist, Herbarium Bogoriense, Indonesia)

Joeni Setijo Rahajoe (Ecologist, Herbarium Bogoriense, Indonesia)

Marlina Ardiyani (Taxonomist, Herbarium Bogoriense, Indonesia)

Himmah Rustiami (Taxonomist, Herbarium Bogoriense, Indonesia)

Lulut Dwi Sulistyaningsih (Taxonomist, Herbarium Bogoriense, Indonesia)

Topik Hidayat (Taxonomist, Indonesia University of Education, Indonesia)

Eizi Suzuki (Ecologist, Kagoshima University, Japan)

Jun Wen (Taxonomist, Smithsonian Natural History Museum, USA)

Barry J. Conn (Taxonomist, School of Life and Environmental Sciences, The University of Sydney, Australia)

David G. Frodin (Taxonomist, Royal Botanic Gardens, Kew, United Kingdom)

Graham Eagleton (Wagstaffe, NSW, Australia)

\section{Secretary}

Ruslan Bukhori

\section{Layout}

Liana Astuti

\section{Illustrators}

Subari

Wahyudi Santoso

Anne Kusumawaty

Correspondence on editorial matters and subscriptions for Reinwardtia should be addressed to:

HERBARIUM BOGORIENSE, BOTANY DIVISION,

RESEARCH CENTER FOR BIOLOGY - INDONESIAN INSTITUTE OF SCIENCES

CIBINONG SCIENCE CENTER, JLN. RAYA JAKARTA - BOGOR KM 46,

CIBINONG 16911, P.O. Box 25 CIBINONG

INDONESIA

PHONE (+62) 21 8765066; Fax (+62) 218765062

E-MAIL: reinwardtia@mail.lipi.go.id

http://e-journal.biologi.lipi.go.id/index.php/reinwardtia

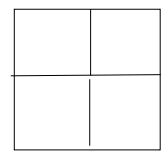

Cover images: Canthiumera robusta K.M.Wong \& X.Y.Ng, spec. nov. Top left: leafy branch with inflorescences; note also keeled stipules. Top right: flower with tufts of pale moniliform hairs visible opposite corolla lobes. Below left: fruits. Below right: pyrenes. Photos: Ang Wee Foong (top left) and X.Y. Ng (remaining images). 
The Editors would like to thank all reviewers of volume 17(2):

Andrew Powling, School of Biological Sciences, University of Portsmouth, Portsmouth, United Kingdom George Argent, Royal Botanic Garden Edinburgh, Edinburgh, United Kingdom

Joan Pereira, Forest Research Centre, Sandakan, Sabah, Malaysia

Jun Yokoyama, Dept. of Biology, Faculty of Science, Yamagata University, Yamagata, Japan

Khoon Meng Wong, Singapore Botanic Gardens, Singapore

Kongkanda Chayamarit, Queen Sirikit Botanic Garden, P.O. Box 7, Mae Rim, Chiang Mai, Thailand 


\title{
RHODODENDRON MEAGAII, A NEW SPECIES OF RHODODENDRON SUBGENUS VIREYA (ERICACEAE) FROM PAPUA, INDONESIA
}

Received 04 May, 2018; accepted 24 September, 2018

\section{YASPER MICHAEL MAMBRASAR}

Herbarium Bogoriense, Botany Division, Research Center for Biology-LIPI, Cibinong Science Center, Jln. Raya Jakarta-Bogor Km.46, Cibinong 16911, Bogor, Indonesia.Email: michael_mambrasar@yahoo.com

\section{PRIMA W. K. HUTABARAT}

Center for Plant Conservation Bogor Botanic Garden-LIPI. Jln. Ir. H. Juanda No. 13, Bogor, 16122, Indonesia. Email: hutabaratpwk@gmail.com

\begin{abstract}
MAMBRASAR, Y. M. \& HUTABARAT, P. W. K. 2018. Rhododendron meagaii, a new species of Rhododendron subgenus Vireya (Ericaceae) from Papua, Indonesia. Reinwardtia 17(2): 97-100. — Rhododendron meagaii, is described and illustrated as a new species in subgenus Vireya (Ericaceae) from Mount Salju, District of Abenaho, Yalimo Regency, Papua Province, Indonesia. Characters distinguishing this new species from related species are discussed.
\end{abstract}

Key words: District of Abenaho, New Guinea, new species, Papua Province, Rhododendron meagaii.

\begin{abstract}
ABSTRAK
MAMBRASAR, Y. M. \& HUTABARAT, P. W. K. 2018. Rhododendron meagaii, jenis baru Rhododendron submarga Vireya (Ericaceae) dari Papua, Indonesia. Reinwardtia 17(2): 97-100. — Rhododendron meagaii, dipertelakan dan digambar sebagai jenis baru pada submarga Vireya (Ericaceae) dari Gunung Salju, Distrik Abenaho, Kabupaten Yalimo, Provinsi Papua, Indonesia. Didiskusikan pula karakter yang membedakan jenis baru ini dengan jenis yang terdekat.
\end{abstract}

Kata kunci: Distrik Abenaho, jenis baru, Provinsi Papua, Pulau Nugini, Rhododendron meagaii.

\section{INTRODUCTION}

New Guinea is a major center diversity of Rhododendron subgenus Vireya in the Malesia region with more than three times the number recorded compared with the next richest island: Borneo (Argent, 2015). The number of species in western New Guinea is greater than in the Eastern part (Papua New Guinea). Argent (2015) recorded 121 species in western New Guinea compared with only 85 species in the eastern part. Rhododendron is well recorded in New Guinea because of its impressive flowers (Kartikasari et al., 2013).

In 2016, during fieldwork in Yalimo regency, Papua Province, the team from LIPI discovered a Rhododendron that appeared to be new. This species is quite distinct from any other Rhododendron species known from western New Guinea. However, there were strong superficial similarities to Rhododendron diesianum Schltr. from eastern New Guinea. On close examination the scale structure and disposition appeared to be sufficiently distinct to consider this new collection as belonging to a different, undescribed species.
Rhododendron meagaii Mambrasar \& Hutabarat spec. nov. - Type: Indonesia, Papua Province, Yalimo Regency, Abenaho District, Mount Salju, 23 May 2016, Michael Mambrasar 239 (Holotype: BO! iso: E! K!). Figs. $1 \& 2$.

Diagnosis. Distinct in section Hadranthe Schltr. in having the combination of characters: elliptic leaves, long stalked dendroid scales, a glabrous corolla and stamens of irregular lengths.

Shrub or small tree to $c a .2 \mathrm{~m}$, twigs densely scaly, $c a$. $2-3 \mathrm{~mm}$ in diameter, internodes $2-6 \mathrm{~cm}$. Leaves in tight pseudowhorls, 3-5 together, spreading. Blade $27-55 \times 7-19 \mathrm{~mm}$, elliptic to narrowly elliptic; base cuneate; apex obtuse to acute occasionally apiculate; margin entire, revolute; when young: densely covered with reddish-brown scales, quickly becoming glabrescent adaxially more slowly abaxially. Scales dendroid, with highly divided arms and long slender stalks, from low persistent epidermal tubercles. Mid-vein impressed above and strongly prominent beneath; lateral veins obscure. Petiole 


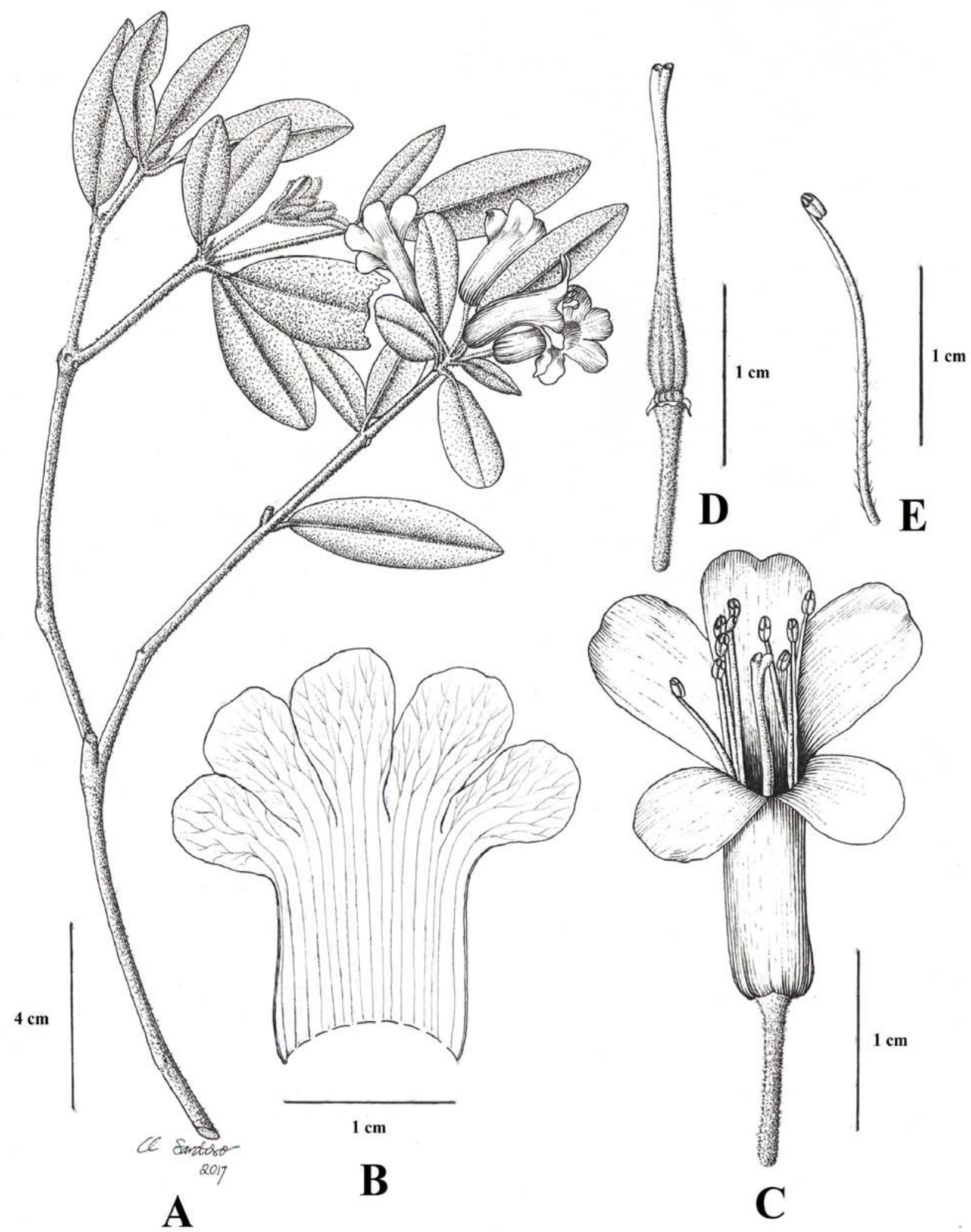

Fig. 1. Rhododendron meagaii Mambrasar \& Hutabarat, spec. nov. A. Branch showing habit of flowers. B. Corrolla opened out. C. Flower. D. Pistil. E. Stamen. From Michael Mambrasar 239 (BO), drawing by Wahyudi Santoso (BO). 


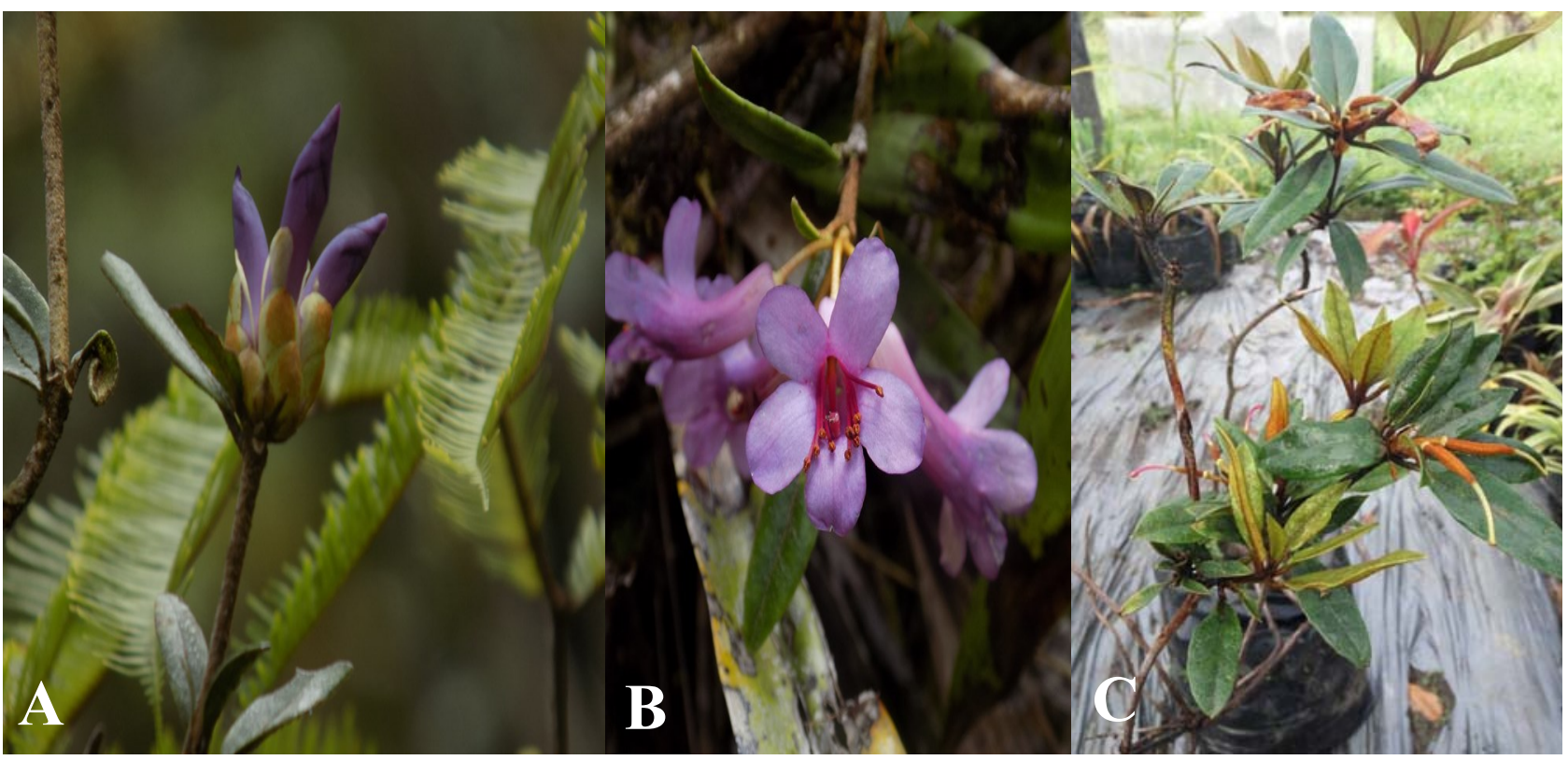

Fig. 2. Rhododendron meagaii Mambrasar \& Hutabarat, spec. nov. A \& B Habit and Flower. Photo taken from type location by Y. Michael Mambrasar (BO). C. Cultivated at Biology Botanical Garden in Wamena (Kebun Raya Biologi Wamena). Photo by Dede Nurul Iman.

$5-7 \times 1 \mathrm{~mm}$, densely stellate scaley, grooved. Flower bud ca. $10 \times 4 \mathrm{~m}$, broadly ellipsoid, the basal bracts spreading, all other bracts appressed. Bracts: the outermost triangular, caudate, densely scaly outside and along the margins; inner bracts to $c a .7 \times 8 \mathrm{~mm}$, ovate to obovate, apiculate, membranous, scaly distally abaxially and along the margins. Bracteoles to $c a .18 \times 1 \mathrm{~mm}$, linear slightly broadened near the apex, with a few marginal scales. Flowers spreading 4-5 together in open umbels. Pedicels: $9-11 \times 0.5 \mathrm{~mm}$, densely brown stellate scaly without simple hairs. Calyx ca. $2 \mathrm{~mm}$ diameter, disk-shaped, the margin undulate, scaly outside, without simple hairs. Corolla zygomorphic, purple, without scent; tube ca. $20 \times 4 \mathrm{~mm}$, curved, glabrous both outside and inside; lobes ca. $8 \times 6 \mathrm{~mm}$, subcircular, glabrous. Stamens 10, unequel in length, slightly exserted, loosely clustered on the upper side of the mouth; filaments 20-22 mm long, sparsely short hairy in the proximal 2/3, glabrous distally. Anthers oblongoid, ca. $2 \mathrm{~mm}$ long. Disk densely short hairy on the upper side. Ovary narrowly fusiform, 6-7 $\mathrm{mm}$ long, densely scaly; style $c a$. 1-1.2 cm long, shortly patently hairy in the proximal $4 \mathrm{~mm}$ and glabrous distally. Stigma ca. $2 \mathrm{~mm}$ in diameter. Fruit cylindrical, densely scaly when young.

Distribution. Known only from the type locality.

Ecology. Mossy forest and open montane shrubbery. Growing with Dicranopteris sp. altitude $1,100 \mathrm{~m}$ asl.

Etymology. Name in honour of Organes Meaga $(\dagger)$, Kebun Raya Biologi Wamena technician who helped in collecting this species.

Phenology. Rhododendron meagaii was observed in flower when it was collected at the middle of May 2016. Later it was reported that the living specimen at the nursery of Kebun Biologi Wamena in Wamena was flowering and fruiting in early June 2017.

\section{Conservation status. Not assessed.}

Note. This species is clearly in section Hadranthe Schltr. displaying the characteristic dendroid scales on distinct epidermal tubercles of that section. It keys to Rhododendron prainianum in Argent (2015), but lacks the distinctive linear leaves of that species. It appears to be most similar to $R$. diesianum Schltr. which occurs much further to the east in New Guinea but that species has scales which are sessile or on much shorter stalks, and has a laxly scaly corolla tube outside.

\section{ACKNOWLEDGEMENTS}

The authors would like to thank (1) KSK Kebun Biologi Wamena for the opportunity to join the 
exploration to Yalimo Regency, (2) Dr. Lina Susanti Juswara, Organes Meaga and Lesman Kogoya for helping to collect the spesimens, (3) the Director of Lorentz National Park and the government of Yalimo regency for granting permission to collect specimens, (4) Dr. George Argent for helpful discussions, (5) Wahyudi Santoso for preparing illustration and (6). Herbarium Bogoriense (BO) for permission for observation in systematic laboratory, (7) Dede Nurul Iman for the pictures and phenology information of the living specimen in Wamena.

\section{REFERENCES}

ARGENT, G. 2015. Rhododendrons of subgenus Vireya $2^{\text {nd }}$ ed. 1-454. Royal Botanic Garden, Edinburgh.

KARTIKASARI, E. N., MARSHALL, A. J. \& BEEHLER, B. M. 2013. Ekologi Papua. $2^{\text {nd }}$ ed. Yayasan Obor Indonesia dan Conservation Indonesia, Jakarta.

SLEUMER, H. 1966. Rhododendron. In: VAN STEENIS, C. G. G. J. (Ed.). Flora Malesiana I (6): 474-668. Wolters-Noordhoff, Groningen. 


\section{INSTRUCTION TO AUTHORS}

Scope. Reinwardtia is a scientific regular journal on plant taxonomy, plant ecology and ethnobotany published in June and December. Manuscript intended for a publication should be written in English.

Titles. Titles should be brief, informative and followed by author's name and mailing address in oneparagraphed.

Abstract. English abstract followed by Indonesian abstract of not more than 250 words. Keywords should be given below each abstract.

Manuscript. Manuscript is or iginal paper and represent an article which has not been published in any other journal or proceedings. The manuscript of no more than 36 pages by using Times New Roman 11, MS Word for Windows of A4 with double spacing, submitted to the editor through Reinwardtia online journal system and < reinwardtia@mail.lipi.go.id>. New paragraph should be indented in by 5 characters. For the style of presentation, authors should follow the latest issue of Reinwardtia very closely. Author(s) should send the preferred running title of the article submitted. Every manuscript will be sent to two blind reviewers.

Identification key. Taxonomic identification key should be prepared using the aligned couplet type.

Nomenclature. Strict adherence to the International Code of Nomenclature is observed, so that taxonomic and nomenclatural novelties should be clearly shown. English description for new taxon proposed should be provided and the herbaria where the type specimens area deposited should be presented. Name of taxon in taxonomic treatment should be presented in the long form that is name of taxon, author's name, year of publication, abbreviated journal or book title, volume, number and page.

Map/line drawing illustration/photograph. Map, line drawing illustration, or photograph preferably should be prepared in landscape presentation to occupy two columns. Illustration must be submitted as original art accompanying, but separated from the manuscript. The illustration should be saved in JPG or GIF format at least 350 pixels. Legends or illustration must be submitted separately at the end of the manuscript.

References. Bibliography, list of literature cited or references follow the Harvard system as the following examples.

Journal : KRAENZLIN, F. 1913. Cyrtandraceae novae Philippinenses I. Philipp. J. Sci. 8: 163-179.

MAYER, V., MOLLER, M., PERRET, M. \& WEBER, A. 2003. Phylogenetic position and generic differentiation of Epithemateae (Gesneriaceae) inferred from plastid DNA sequence data. American J. Bot. 90: 321-329.

Proceedings : TEMU, S. T. 1995. Peranan tumbuhan dan ternak dalam upacara adat "Djoka Dju" pada suku Lio, Ende, Flores, Nusa Tenggara Timur. In: NASUTION, E. (Ed.). Prosiding Seminar dan Lokakarya Nasional Etnobotani II. LIPI \& Perpustakaan Nasional: 263-268. (In Indonesian).

SIMBOLON, H. \& MIRMANTO, E. 2000. Checklist of plant species in the peat swamp forests of Central Kalimantan, Indonesia. In: IWAKUMA, T., INOUE, T., KOHYAMA, T., OSAKI, M., SIMBOLON, H., TACHIBANA, H., TAKAHASHI, H., TANAKA, N., YABE, K. (Eds.). Proceedings of the International Symposium on: Tropical Peatlands. Pp.179 - 190.

Book : RIDLEY, H. N. 1923. Flora of the Malay Peninsula 2. L. Reeve \& Co. Ltd, London.

Part of Book : BENTHAM, G. 1876. Gesneriaceae. In: BENTHAM, G. \& HOOKER, J. D. Genera Plantarum 2. Lovell Reeve \& Co., London. Pp. 990-1025.

Thesis : BAIRD, L. 2002. A Grammar of Kéo: An Austronesian Language of East Nusantara. Australian National University, Canberra. [PhD. Thesis].

Website : http://www.nationaalherbarium.nl/fmcollectors/k/KostermansAJGH.html. (Accessed 15 February 2012). 


\section{Reinwardtia}

Published by Herbarium Bogoriense, Botany Division, Research Center for Biology, Indonesian Institute of Sciences

Address: Jln. Raya Jakarta-Bogor Km. 46 Cibinong 16911, P.O. Box 25 Cibinong

Telp. (+62) 21 8765066; Fax (+62) 218765062

LIPI

Email: reinwardtia@mail.lipi.go.id

\section{REINWARDTIA Author Agreement Form}

Title of article

Name of Author(s) :

I/We hereby declare that:

- $\mathrm{My} / \mathrm{Our}$ manuscript was based on my/our original work.

- It was not published or submitted to other journal for publication.

- I/we agree to publish my/our manuscript and the copyright of this article is owned by Reinwardtia.

- We have obtained written permission from copyright owners for any excerpts from copyrighted works that are included and have credited the sources in our article. 



\section{REINWARDTIA}

Vol. 17. No. 2. 2018

CONTENTS

LAODE ALHAMD. Ecological study of the arrowroot (Tacca leontopetaloides (L.) Kuntze) at Karimunjawa National Park (KNP), Central Java

YASPER MICHAEL MAMBRASAR \& PRIMA W. K. HUTABARAT. Rhododendron meagaii, a new species of Rhododendron subgenus Vireya (Ericaceae) from Papua, Indonesia

K. M. WONG, RIDHA MAHYUNI, XIN YI NG \& LOUISE NEO. Flora of Singapore Precursors, 8. Systematy of the new Southeast Asian genera Canthiumera and Dibridsonia (Rubiaceae: Vanguerieae), with notes on plant architecture and reproductive ecology

ANDREW POWLING. An assessment of present plant diversity on the Natewa Peninsula, Vanua Levu, Fiji 125

ASEP SADILI, KUSWATA KARTAWINATA, HERWASONO SOEDJITO \& EDY NASRIADI SAMBAS. Tree species diversity in a pristine montane forest previously untouched by human activities in Foja Mountains, Papua, Indonesia

Reinwardtia is a LIPI accredited Journal (792/AU3/P2MI-LIPI/04/2016)

http://e-journal.biologi.lipi.go.id/index.php/reinwardtia

Herbarium Bogoriense

Botany Division

Research Center for Biology - Indonesian Institute of Sciences

Cibinong Science Center

Jln. Raya Jakarta - Bogor, Km 46

Cibinong 16911, P.O. Box 25 Cibinong

Indonesia 